\title{
Economic Enhancement of Western Shale Oil Upgrading
}

\author{
Topical Report
}

\author{
J.W. Bunger \\ H. Ryu \\ S-Y.Jeong
}

July 1989

Work Performed Under Cooperative Agreement: DE-FC21-86MC11076

For

U.S. Department of Energy

Office of Fossil Energy

Morgantown Energy Technology Center

Morgantown, West Virginia

By

Western Research Institute

Laramie, Wyoming

and

University of Utah

Salt Lake City, Utah 


\section{DISCLAIMER}

This report was prepared as an account of work sponsored by an agency of the United States Government. Neither the United States Government nor any agency Thereof, nor any of their employees, makes any warranty, express or implied, or assumes any legal liability or responsibility for the accuracy, completeness, or usefulness of any information, apparatus, product, or process disclosed, or represents that its use would not infringe privately owned rights. Reference herein to any specific commercial product, process, or service by trade name, trademark, manufacturer, or otherwise does not necessarily constitute or imply its endorsement, recommendation, or favoring by the United States Government or any agency thereof. The views and opinions of authors expressed herein do not necessarily state or reflect those of the United States Government or any agency thereof. 


\section{DISCLAIMER}

Portions of this document may be illegible in electronic image products. Images are produced from the best available original document. 


\section{DISCLAIMER}

This report was prepared as an account of work sponsored by an agency of the United States Government. Neither the United States Government nor any agency thereof, nor any of their employees makes any warranty, express of implied, or assumes any legal liability or responsibility for the accuracy, completeness or usefulness of any information, apparatus, product, or process disclosed, or represents that its use would not infringe privately owned rights. Reference herein to any specific commercial product, process, or service by trade name, trademark, manufacturer, or otherwise, does not necessarily constitute or imply its endorsement, recommendation, or favoring by the United States Government or any agency thereof. The views and opinions of authors expressed herein do not necessarily state or reflect those of the United States Government or any agency thereof.

This report has been reproduced directly from the best available copy.

Available to DOE and DOE contractors from the Office of Scientific and Technical Information, P.O. Box 62, Oak Ridge, TN 37831; prices available from (615)576-8401, FTS 626-8401.

Available to the public from the National Technical Information Service, U.S. Department of Commerce, 5285 Port Royal Rd., Springficld, VA 22161.

Price: Printed copy AO3

Microfiche $\mathrm{AOl}$

Codes are used for pricing all publications. The code is determined by the number of pages in the publication. Information pertaining to the pricing codes can be found in the current issues of the following publications, which are generally available in most libraries: Energy Research Abstracts (ERA), Government Reports Announcements and Index (GRA and I); Scientific and Technical Abstracts Reports (STAR); and publication NTIS-PR-360 available from NTIS at the above address. 
Economic Enhancement of Western Shale Oil Upgrading

\author{
Topical Report
}

\author{
J.W. Bunger \\ H. Ryu \\ S-Y. Jeong
}

Work Performed Under Cooperative Agreement: DE-FC21-86MC11076

For

U.S. Department of Energy

Office of Fossil Energy

Morgantown Energy Technology Center

P.O. Box 880

Morgantown, West Virginia 26507-0880

Western Research Institute

P.O. Box 3395

University Station

Laramie, Wyoming 82071

and

University of Utah

Department of Fuels Engineering

Salt Lake City, Utah 84112-1183

July 1989 
TABLE OF CONTENTS

Page

Executive Summary $\ldots \ldots \ldots \ldots \ldots \ldots \ldots \ldots \ldots \ldots \ldots \ldots \ldots \ldots$

Definition of the Problem and Objectives $\ldots \ldots \ldots \ldots \ldots \ldots \ldots \ldots \ldots \ldots \ldots \ldots \ldots \ldots \ldots$

Process Description $\ldots \ldots \ldots \ldots \ldots \ldots \ldots \ldots \ldots \ldots \ldots \ldots \ldots \ldots \ldots$

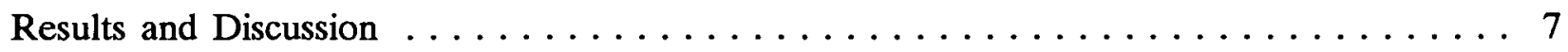

Theoretical Development for Catalytic Process Model $\ldots \ldots \ldots \ldots \ldots \ldots \ldots$

Shale Oil Characteristics $\ldots \ldots \ldots \ldots \ldots \ldots \ldots \ldots \ldots$

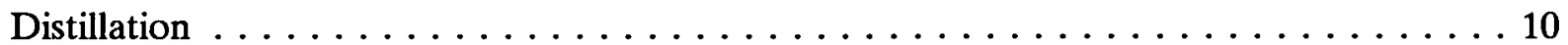

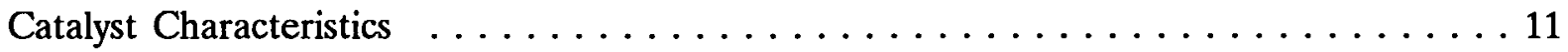

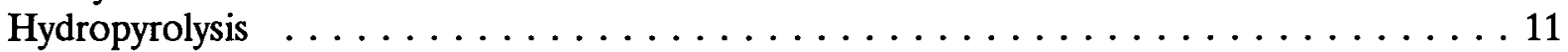

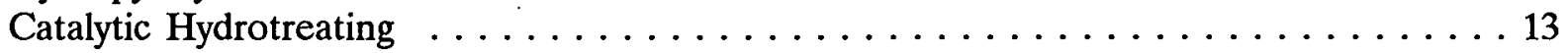

Discussion of Conventional and SOR Results $\ldots \ldots \ldots \ldots \ldots \ldots \ldots \ldots \ldots \ldots \ldots$

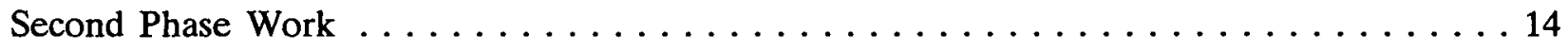

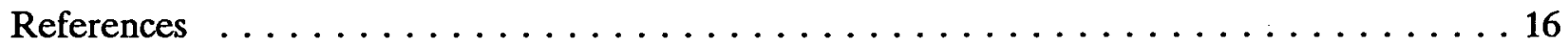

\section{LIST OF TABLES}

$\underline{\text { Table }}$

Page

1 Elemental Analysis and Physical Properties of Raw Shale Oil . . . . . . . . 17

2 Boiling Point Distribution of the WRI As Received and Topped Shale Oil . . . . . 18

3 Boiling Point Distribution of Fractional Distillation Cuts from WRI Shale Oil . . . . 19

$4 \quad$ Physical and Thermodynamic Properties of Distillate Fraction @20 and 400 ${ }^{\circ} \mathrm{C} \ldots 20$

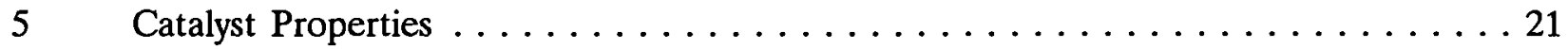

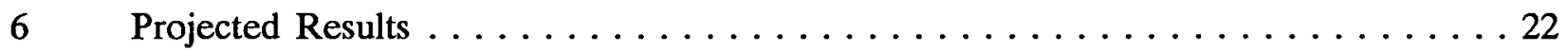

\section{LIST OF FIGURES}

Figure $\quad$ Page

1 Composition of Feed Streams and Adsorbed Species $\ldots \ldots \ldots \ldots \ldots$

$2 \quad$ Shale Oil Upgrading Process

Flow Diagram and Material Balance Projected . . . . . . . . . . . . 24

3 Yield of Products from Hydropyrolysis of Shale Oil as a Function of

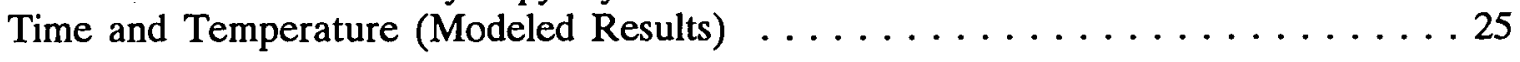




\title{
ECONOMIC ENHANCEMENT OF WESTERN SHALE OIL UPGRADING
}

\author{
by
}

\author{
James W. Bunger, Principal Investigator \\ Hoil Ryu, Graduate Student \\ Soon-Yong Jeong, Graduate Student
}

\section{EXECUTIVE SUMMARY}

A proof-of-concept study for a novel shale oil refining process was undertaken. This project promises reduced upgrading costs, thereby making shale oil development more feasible for commercialization. The process consists of distillation of raw shale oil into a distillate and residue portion, cracking of the residue by hydropyrolysis, and selective hydrotreating of narrow boiling cuts from the total distillate. Based on models and experimental data, the end product slate is projected to be $34 \%$ naphtha, $57 \%$ middle distillate, and $10.3 \%$ atm residue + coke. Hydrogen addition is $1.3 \%$ or $800 \mathrm{scf} / \mathrm{bbl}$. These results are considerably improved over conventional processing, which gives $14 \%$ naphtha, $41 \%$ middle distillate, and $48.2 \%$ residue + coke and hydrogen addition of $3.2 \%$ or $2000 \mathrm{scf} / \mathrm{bbl}$. More quantitative data and preliminary economics will be obtained in the next phase of study.

\section{DEFINITION OF THE PROBLEM AND OBJECTIVES}

Upgrading of raw shale oil to refinery-acceptable crude oil adds significantly to the cost of shale oil production. The high cost of upgrading contributes to the marginal economics for oil shale commercialization. An improvement in the efficiency of shale oil upgrading and a reduction in costs would help advance the development of oil shale in the United States.

Currently practiced upgrading approaches encounter several difficulties which must be addressed in any advanced upgrading process. Raw shalc oil contains appreciable quantities of particulates and metals such as vanadium, nickel, iron, and arsenic. The presence of iron and 
arsenic is particularly significant because catalysts used in conventional petroleum processing have not been designed for the presence of these metals.

Shale oil also contains high concentrations of nitrogen which must be removed catalytically before the shale oil is acceptable as a feedstock to a conventional petroleum refinery. Shale oil also contains large quantities of conjugated olefins, such as indenes, indoles, and pyrroles, which are difficult to completely hydrogenate but which, when left in the shale oil, cause long-term instability of the shale-oil product.

Much of the difficulty with nitrogen removal relates to the catalytic hydroprocessing of the heavy ends of the shale oil. Atmospheric residue typically constitutes $50 \%$ or more of the raw shale oil. To effect nitrogen removal from this material, high-process severities are required which result in high hydrogen consumption and reduced catalyst life due to coking reactions. High severities result in poor control over product slates.

The literature contains numerous articles on shale oil upgrading and processing. ${ }^{1-3}$ Various schemes are proposed for dealing with the inherent difficulties of shale oils. Some schemes involve prior coking of the raw shale oil to reduce the molecular weight and to sequester undesirable inorganics in the coke. While such schemes make the down-stream catalytic processing easier, coking results in a significant loss in yield; the advantages obtained are offset by the higher costs in the mining and retorting processes. Larger amounts of material must be handled to obtain a given output of product.

Upgrading and converting the entire raw shale oil distillation profile to high value marketable products has not yet been achieved. Most often, a significant portion of the final product is sold for fuel oil, because of the cost and difficulty in converting the residual end of shale oil to transportation fuels. At the present time conventional refineries will not accept a raw shale 
oil and catalytic hydroprocessing must be effected prior to refining.

Shale oil from Colorado is currently being upgraded at the several-thousand bbl/day level by UNOCAL. ${ }^{4}$ The upgrading sequence consists of passing raw shale oil over a catalyst/guard bed to remove metals and particulates. The shale oil then passes over hydrotreating catalysts for nitrogen and sulfur removal and for hydrogenation of olefins. Mild hydrocracking of paraffins may be included for pour point control.

For sequences which do not involve hydrocracking, the hydrogen requirements for denitrogenation typically exceed $2,000 \mathrm{scf} / \mathrm{bbl} .^{5}$ For these approaches, less than $15 \%$ of the finished product boils in the naphtha range $\left(80\right.$ to $\left.200^{\circ} \mathrm{C}\right)$. This means that additional cracking and hydroprocessing is required at the refinery for production of gasoline and middle distillates (diesel or aviation turbine fuels). Thus, currently practiced technology. results in high hydrogen consumption, low yields of products in the desirable boiling range, and less than desirable catalyst life.

Calculations show that complete removal of nitrogen, sulfur, and oxygen to form $\mathrm{NH}_{3}, \mathrm{H}_{2} \mathrm{~S}$, and $\mathrm{H}_{2} \mathrm{O}$, respectively, and saturation of olefinic bonds requires approximately $800 \mathrm{scf} / \mathrm{bbl}$. Additionally, ring hydrogenation is required for certain structures to allow removal of ring heteroatoms. Theoretical thermodynamic considerations suggest that high selectivity for HDN, HDS/HYD cannot be accomplished when operating at high process severities. Theoretical considerations have also shown that high selectivity is extremely difficult when processing higher molecular weight aromatics. Condensed aromatics of two rings or larger are more susceptible to hydrogenation than are single-ring aromatics. 
The high rate of catalyst deactivation and the inability to project a cost effective refining and market option for the residual portion make the assessment of upgrading costs very difficult. There are three basic characteristics of raw shale oil which contribute to the high costs of upgrading and refining which must be addressed in any advanced scheme for processing these materials. The first of these is the metals and particulates content; the second of these is the extraordinarily high nitrogen content, much of which is pyrrolic in nature, and these types are not found in the same level of concentration in conventional petroleums; the third characteristic is the relatively large fraction of atmospheric resid in comparison to light and middle distillate. Ordinarily, the atmospheric resid or vacuum gas oil is charged to catalytic crackers, but the high nitrogen content of these high boiling materials makes the catalytic cracking option unacceptably expensive. An advanced upgrading and refining approach must account for these three critical factors.

An advanced shale oil upgrading process would involve cost-effective removal of inorganics and metals, accomplish selective utilization of hydrogen, and maximize the yield of low-to-middle boiling distillates. The upgrading process studied under this project promises to accomplish these objectives. The approach maximizes liquid yields and minimizes hydrogen consumption while meeting criteria for refinery acceptability. The process promises higher process efficiency and is expected to result in significantly reduced shale oil upgrading costs.

\section{PROCESS DESCRIPTION}

Hydropyrolysis is a process which has been under development at the University of Utah for more than a decade..$^{6.9}$ The Utah hydropyrolysis process is a short-residence time $(1-3 \mathrm{sec}$.) moderate temperature $\left(S \cup U-600^{\circ} \mathcal{C}\right)$ process for the cracking of residual materials to distillate products. Feedstock is introduced to the reaction zone containing $1,200-2,000$ psig $\mathbf{H}_{2}$ by use of 
a spray nozzle. Hydrogen participates in the reaction by metathesis reactions with hydrocarbon free radicals. Hydrogen atoms produced in the metathesis reactions accelerate cracking, dealkylation, cracking of naphthenic compounds, and partial hydrogenation of PNA's.

During hydropyrolysis, reduction of molecular weight occurs with virtually no production of coke. Coke-forming reactions are almost completely inhibited by the action of hydrogen and the dilute phase of the reaction regime..$^{10-12}$ Reduction of the molecular weight is achieved with very modest net hydrogen consumption. A reduction of average molecular weight by $50 \%$ is typically accompanied by a net hydrogen consumption of only $200-300 \mathrm{scf} / \mathrm{bbl}$. Theoretical calculations show that this is very close to the minimum hydrogen requirements for one cracking event per molecule, assuming that there is no net dehydrogenation of naphthenes to aromatics.

An important feature of hydropyrolysis is its relative insensitivity to inorganics and metals. These species do not adversely affect the process and tend to report to the unreacted residual portion of the products. The process may be operated at low severities to minimize gas production and unreacted material can be recycled to improve the conversion. A small drag stream of the heaviest components containing the majority of the particulates and metals is removed from the reaction system. Thus, hydropyrolysis is a process which promises to convert heavy shale oil to distillate products in high yields and with low consumption of hydrogen.

An equally important discovery has been made in the catalytic processing research conducted. In a study to determine the effect of adsorption thermodynamics on catalytic reaction, it has been learned that the value of the adsorption constant $\mathrm{K}_{\mathrm{ads}}$ is a strong function of molecular weight. Structural features, including the presence of most heteroatoms, played a secondary role in determining the magnitude of $\mathrm{K}_{\mathrm{ads}}$. In the first order reaction rate equation:

$$
r=k_{a} A /\left(1+\Sigma K_{i} X_{i}\right)
$$


The adsorption constant for non-reacting species appears as an inhibition term in the denominator. If $\mathrm{K}_{\mathrm{i}}>>\mathrm{Ka}$, then strong inhibition is expected. If a feedstock exhibiting a broad range of molecular weights is passed over a catalytic surface, the highest molecular weight species will successfully compete for adsorption on the surface, displacing lower molecular weight species and thereby inhibiting the opportunity for these lower molecular weight species to react.

This phenomenon is illustrated graphically in Figure 1. Figure 1a depicts a feedstock which has a broad molecular weight range with an average of $300 \mathrm{amu}$. When this material is passed over a catalyst surface, under steady state conditions, the molecular weight distribution of the adsorbed species is shown by the "dashed" line. At a temperature of $350^{\circ} \mathrm{C}$, all but the highest molecular weight species are effectively excluded from the surface. An increase in temperature to $410^{\circ} \mathrm{C}$ improves the situation, but it is still clear that a large fraction of the feedstock is inhibited from adsorption. Figure $1 b$ illustrates the case in which a narrower molecular weight range material is passed over the catalyst. In this case, a much larger fraction of the feedstock participates in the adsorption process and thereby is afforded an opportunity to react.

The implications of these findings to shale oil processing are obvious. If shale oil upgrading is to be achieved with high selectivity and acceptable conversions at moderate process severities, the feedstock to the catalytic process must be of a narrow molecular weight range. A narrow molesular weight range is most conveniently achieved through distillation into narrow boiling cuts (here it is recognized that the effect of structural differences in molecules will limit how narrow the range can be). The practical limit in how narrow the fraction should be and how many parallel hydrotreaters are required is, in fact, an economic question which would constitute a significant portion of the second phase of the program. 
The SOR sequence is illustrated in the flow diagram shown in Figure 2. The initial step in the process is a fractionation of raw shale oil into an atmospheric distillate and an atmospheric resid. The resid, which contains the vast majority of the inorganics, is fed to the hydropyrolysis reactor designed to operate at moderate, e.g., 70\%, once-through conversions. Unreacted material is recycled to improve the conversions. By operating at modest severities, high conversions to distillable liquids with low hydrogen consumption is achieved.

The distillate material, boiling in the range of $80-350^{\circ} \mathrm{C}$ is recombined with the overhead in the original distillation step. This material is fractionated in a high efficiency column to produce " $\mathrm{n}$ " fractions for hydrotreating. Hydrotreating is conducted in parallel reactors under conditions specifically tailored for the distillate cut. The hydrotreaters may or may not contain guard beds, depending upon the metals content of the fuel.

\section{RESULTS AND DISCUSSION}

Theoretical Development for Catalytic Process Model

Conversion in catalytic processing will be a function of four variables: (1) $\alpha^{*},(2)\left(a^{*}-a\right),(3)$ a $\uparrow$, and (4) $m_{o}$. These variables are defined in the following equations:

$$
\begin{aligned}
& \mathrm{K}_{\mathrm{abs}}=\mathrm{K}^{*} \mathrm{e}^{\mathrm{a}^{*} \mathrm{~m}} \\
& \mathrm{~K}_{\text {rate }}=\mathrm{K}_{\mathrm{o}} \mathrm{e}^{-\mathrm{am}}
\end{aligned}
$$

MW distribution $=\mathrm{e}^{-\mathrm{a} \dagger\left(\mathrm{m}-\mathrm{m}_{\mathrm{o}}\right)^{2}}$

where in each of these, $\mathrm{m}=$ molecular weight. Also, 


$$
\alpha^{*}=\frac{A \text { S L K }{ }_{0}^{*}}{M}
$$

where: $\quad \mathrm{A}=$ cross-section area of reactor;

$$
\mathrm{L}=\text { length of reactor; }
$$

$S=$ number of active sites on the catalyst per cc of reactor; and

$$
\mathbf{M}=\text { hydrocarbon flow rate, moles/sec. }
$$

Since a conversion for a set of the four variables must be obtained by computer numerical integration, much time will be needed to fill out a table of conversion over appropriate ranges of the four variables. Then an empirical fit to that set of numbers would give the desired general equation. So the equation can be obtained, but it will take a good deal of computer analysis.

In our mathematical model for hydrotreating a given feed over a given catalyst, we let the equilibrium absorption constant, $\mathrm{K}_{\mathrm{a}}$, be a function only of molecular weight, $\mathrm{m}$, and the reaction rate constant for absorbed species, $\mathrm{K}_{\mathrm{r}}$ is likewise just a function of $\mathrm{m}$ :

$$
\begin{aligned}
& \mathrm{K}_{\mathrm{a}}=\mathrm{k}^{* \mathrm{a}^{*} \mathrm{~m}} \\
& \mathrm{~K}_{\mathrm{r}}=\mathrm{K}_{\mathrm{o}} \mathrm{e}^{-\mathrm{am}}
\end{aligned}
$$

In our experimental work, we will know the molecular weight distribution of the feed, a distillate cut from the shale oil. So in our mathematical model, the conversion will be a function only of two as yet unknown paramcters, $\left(a^{*}-a\right)$ and $\alpha^{*}$ as defined above.

Note that the unknown part of $\alpha^{*}$ is:

$$
\alpha_{0}^{*}=S K_{0} K^{*}
$$


Thus we have two unknown parameters, $\left(\mathrm{a}^{*}-\mathrm{a}\right)$ and $\alpha_{0}{ }^{*}$, and numerous data points of known conversion for known feed and residence time. We have worked out an effective strategy to obtain $\left(a^{*}-a\right)$ and $\alpha_{0}^{*}$ through a least-squares type analysis of this data. Such a result will now allow us to predict conversion for any distillate cut from the shale oil reacting over the given catalyst in any reactor configuration and for any residence time. We note that we could improve the prediction, if needed, by letting $K_{a}$ and $K_{T}$ be functions of $z$ and $i$ as well as $m$ (see Z-BASIC method). ${ }^{13}$

\section{Shale Oil Characteristics}

The shale oil characteristics are shown in Table 1. Samples of shale oil were obtained from the Western Research Institute (WRI) and the New Paraho Shale Oil Corporation. The samples have been subjected to elemental analysis and certain physical properties measurements. The data in Table 1 show that the Paraho shale oil has a slightly higher density and viscosity and lower volatility. In selecting a sample for use, consideration was given to the two principal experimental tasks of the program, namely, the hydropyrolysis and hydrotreating. The Paraho shale oil is a better test sample for the hydropyrolysis because of its higher residue content. The WRI sample is a better test sample for the hydrotreating portion because of its higher yield of distillate. Ultimately, the value of the concept is expected to be greatest for those processes which provide a high yield of shale oil based on Fischer assay, but which also may contain higher percentages of atmospheric resid. The data shown in Table 1 are typical for shale oils, and reveal the large percentage of material boiling in the atmospheric and vacuum distillate and residue range. Both of these samples represent good cases for study for the proof-of-concept of the shale oil refining process. 


\section{Distillation}

The WRI shale oil was subjected to thin-film distillation for purposes of topping the shale and removing the most volatile components. These components are easily hydrotreatable, but their presence in the samples results in increasing difficulties with material balances and their removal will improve the final results. The fractional distillation compositions of the as-received shale oil and the topped shale oil are shown in Table 2. Approximately 12.4 percent of the shale oil was distilled and condensed. The light end condensate exhibited an API gravity of $40.8^{\circ}$. The topped shale oil, representing nearly $16 \mathrm{~kg}$ of material and 87.6 percent of the original material exhibited an API gravity of $22^{\circ}$. The simulated distillation data for these two samples is shown in Table 2 .

The degassed and topped WRI shale oil was further distilled by semi-cal fractional distillation to obtain three narrow fractions and a residue. The three fractions are representative of the $200-275,275-365$, and $365-455^{\circ} \mathrm{C}$ boiling ranges. The efficiency of the separation was determined by simulated distillation analysis of the three fractions. These results are shown in Table 3.

PROCESS SIMULATION developed by Simulation Sciences, Inc., was used to calculate the important physical and thermodynamic properties of these three fractions based on a pseudocomponent concept. These results, taken at the ambient temperature case and the $400^{\circ} \mathrm{C}$ case, are shown in Table 4. These distillates were used for the hydrotreating studies. Also used for the hydrotreating studies was a blended sample of the three distillates blended in equal weight proportions. 


\section{Catalyst Characteristics}

For purposes of the proof of concept studies, the particular selection of catalyst is not critical. However, due to the design and optimization tasks to be conducted in the second year of the study, it was important that a meaningful catalyst be selected because the results could ultimately form the baseline for comparison with other candidate catalysts.

Two catalysts were selected and obtained from Shell Development Company. The properties of these two $1 / 16$ inch catalysts are listed in Table 5. The data in the table show that the chemical composition is nearly identical with the 344 catalyst possessing a lower specific surface area compared to the 444 catalyst. Catalysts of lower specific surface area typically exhibit higher average pore diameters. For purposes of this study, it was desirable to limit the diffusion effects as much as possible so that the conversions and rates measured are more representative of the intrinsic catalytic reaction rates. Therefore, the 344 catalyst was selected for initial study.

\section{Hydropyrolysis}

Hydropyrolysis is a short residence time, non-catalytic thermal hydrocracking process for reducing the molecular weight of residual components without the formation of coke. Hydropyrolysis may ideally crack atmospheric and vacuum resid to atmospheric distillate, rendering the nitrogen and sulfur compounds amenable to conventional catalytic hydrotreating. Experimental difficulties with the hydropyrolysis unit and delays in the generation of distillate samples by the high efficiency distillation have prevented hydropyrolysis processing of shale oil resid to be completed in the present reporting period.

In order to obtain data and an estimate of the hydropyrolysis yields for shale oil, characterization data for the shale oil resid were used as input data for our kinetic model of the 
hydropyrolysis process to predict the yield distribution as a function of temperature and residence time. ${ }^{13}$

The complex mixture is separated into specified boiling ranges to provide individual products of commercial importance such as residue (R), atmospheric and vacuum distillate (AVD), naphtha and middle distillate (NMD), and gas (G). The knowledge that molecular weight is a strong function of its boiling point and material of high molecular weight cracks to lower molecular weight species suggests the following relatively simple scheme for representing the overall kinetics:

$$
\text { R } \rightarrow \text { AVD } \rightarrow-\cdots \text { NMD }
$$

G

where $R$ is the weight fraction of residue exhibiting a nominal boiling point above $538^{\circ} \mathrm{C}, \mathrm{AVD}$ is the weight fraction of atmospheric and vacuum distillate with a nominal boiling point of 275$538^{\circ} \mathrm{C}, \mathrm{NMD}$ is the weight fraction of naphtha and middle distillate boiling at 1 atm up to $275^{\circ} \mathrm{C}$ $\left(\mathrm{C}_{5}-275^{\circ} \mathrm{C}\right)$, and $\mathrm{G}$ represents the weight fraction of gases $\left(\mathrm{C}_{4}\right.$ 's, dry gas).

The predicted yield pattern is shown in Figure 3 A-D and revealed that at high severity of temperature and residence time, high conversions of residue to light distillate and gas is predicted. At more moderate (and probably more optimum) conditions, approximating $525^{\circ} \mathrm{C}$ and 5 seconds residence time, the predicted yield structure is 8 percent gas, 38 percent naphtha plus middle distillate, 18 percent atmospheric and vacuum distillate, and 18 percent residue. These compositions represent the outlet composition at nominal ambient conditions and includes recycle gas. The unreacted heavy materials and gases at the reactor outlet will be continuously recycled. The concentration of each lump at zero time was taken to be equal to the concentration of reactor inlet. 
With regard to the residue, it may be fairly noted that the process model is based on tar sand bitumen which possesses typically over 50 percent vacuum residue and is expected to be considerably less tractable to hydropyrolysis than would be a shale oil resid. Thus, it is expected that actual hydropyrolysis data will show considerably greater conversions of the residue than is predicted by the currently available model. Properly configured, it is thought possible to recycle the residue portion to extinction, thereby dramatically improving the yield of distillate in comparison to that contained in the raw shale oil.

\section{Catalytic Hydrotreating}

The equipment used in this study is a trickle bed reactor charged with about $50 \mathrm{~g}$ of catalyst. Process conditions were selected to provide mild conversions, thereby providing high sensitivity to changes in feedstock composition and process conditions. Process conditions used for the line-out studies were:

$$
\begin{aligned}
& \mathrm{T}=375^{\circ} \mathrm{C} ; \\
& \mathrm{P}=1500 \mathrm{psig} \mathrm{H}_{2} \\
& \mathrm{WHSV}=0.86 / \mathrm{hr} ; \\
& \mathrm{H}_{2} \text { flow }=3000 \mathrm{scf} / \mathrm{bbl} \text {; and } \\
& \text { catalyst }=\text { Shell } 344 \mathrm{~T} / \mathrm{L} 1 / 16 .
\end{aligned}
$$

Under these conditions, approximately $70 \% \mathrm{HDN}$ is achieved.

Experimental results of processing of distillates are too preliminary to report at this time. Calculations suggest that by processing narrow boiling distillates under identical conditions that conversions of $85 \%$ would be achieved. However, the presence of the residual "tail" in the whole shale oil tends to make the calculations appear worse than would actually be experienced. 
Quantitative data will be obtained in the early stages of the next phase.

Discussion of Conventional and SOR Results

Calculated results from the SOR process are compared with conventional upgrading results as shown in Table 6. As can be seen, a major difference in product slate is calculated and lower hydrogen consumption is expected. These results clearly demonstrate the major differences expected from the refining approach. Further experimental verification of these projected results will be conducted during the next phase of study.

\section{SECOND PHASE WORK}

The second phase of this research will consist of developing more quantitative data required for preliminary optimization of the process. Experimental work will be conducted to systematically determine important pre-design data for engineering purposes. The tasks will involve the development of the reaction engineering model which will include the effect of process variables on yield, product composition, hydrogen consumption, and level of hydrodenitrogenation. This model will include estimates of the effect of operating conditions such as residence times, catalyst to oil ratios, temperatures, throughput rates, distillation conditions, and pressure. The reaction engineering model will form the basis for a process simulation and optimization exercise. 
Patentable innovations are anticipated and will be disclosed to the Office of Technology Transfer at the University of Utah, which will make the technology available for license for commercial development. Subsequent activities (Phase III and beyond) will be required to complete engineering design data, to test the general applicability to shale oils, and to ascertain preferred catalyst compositions and structures. Phase III funds will be sought for these purposes, both through the Western Shale Oil Consortium and from other government and private sources. 


\section{REFERENCES}

1. Sladek, T.A., Poulton, P.L., Davis, W.E., and Robinson, P.A., "A Technology Assessment of Oil Shale Development," 13th Oil Shale Symp. Proc., CSM-1980.

2. Ranney, M.W., "Shale Oil Refining and Purification Processes," Oil Shale and Tar Sands Technology, Recent Developments, p. 233, Noyes Data Corporation, 1979.

3. Hendrickson, T.A., Synthetic Fuels Data Handbook, Cameron Eng., Inc., 1978.

4. Personal Communication, UNOCAL, Feb. 1989.

5. Sullivan, R.F., and Stangeland, B.E., Chapt. 3, Refining of Synthetic Crudes, Gorbaty, M.L., and Harncy, B.M., eds., ACS - Adv. Chem. Ser., 179, pp 25-25 (1979).

6. Bunger, J.W., and Cogswell, D.E., "Characteristics of Tar Sand Bitumen Asphaltenes as Studied by Conversion of Bitumen by Hydropyrolysis," Ch. 13 of Chemistry of Asphaltenes, J.W. Bunger, N.C. Li (eds.). Advances in Chemistry Series - 195, American Chemical Society, 1981.

7. Bunger, J.W., Cogswell, D.E., and Oblad, A.G., "Hydropyrolysis - Potential for Primary Upgrading" in Oil Shale, Tar Sands and Related Materials, Harry Stauffer, ed., ACS Symposium Series - 163, Chapter 25, pp. 369-380.

8. Bunger, J.W., and Oblad, A.G., "Upgrading of Bitumen by Hydropyrolysis - A Process for Low Coke and High Syncrude Yields," Proc. Third Internat. Conf. of Heavy Crude and Tar Sands, UNITAR/UNDP Information Center New York City, Los Angeles, CA, pp. 1717-1726, July 22-31, 1985.

9. Bunger, J.W., Tsai, C.H., Ryu, H., and Devineni, P., "Developments in Upgrading of Bitumen by Hydropyrolysis," Proceedings, 4th International Conference on Heavy Crude and Tar Sands, UNITAR/UNDP, Edmonton, Canada.

10. Bunger, J.W., "Reactions of Hydrogen During Hydropyrolysis Processing of Heavy Crudes," Preprints, Div. Petr. Chem., Amer. Chem. Soc. 30(4) 658-663 (1985).

11. Bunger, J.W., "Inhibition of Coke Formation in Hydropyrolysis of Residual Oils," Preprints, Div. Petr. Chem., Amer. Chem. Soc. 30(3) 549-554 (1985).

12. Tsai, Chung Hsi, "Kinetics of Hydropyrolysis of Tar Sand Bitumen and Related Material," M.S. Thesis, Dept. of Fuels Engineering, University of Utah, 1986.

13. Ryu, H. Ph.D. Dissertation, Dept. of Fuels Engineering, 1989 (to be published). 
Table 1

Elemental Analysis and Physical Properties

of Raw Shale Oil

\begin{tabular}{|c|c|c|}
\hline & Paraho & WRI \\
\hline \multicolumn{3}{|l|}{ Element } \\
\hline $\begin{array}{l}\mathrm{C} \\
\mathrm{H} \\
\mathrm{N} \\
\mathrm{S} \\
\mathrm{O} \text { (diff) } \\
\mathrm{C} / \mathrm{H}\end{array}$ & $\begin{array}{c}82.02 \\
11.07 \\
1.87 \\
0.71 \\
4.34 \\
0.617\end{array}$ & $\begin{array}{l}83.08 \\
11.67 \\
1.47 \\
1.036 \\
2.74 \\
0.593\end{array}$ \\
\hline \multicolumn{3}{|l|}{ Property } \\
\hline $\begin{array}{l}\text { Sp. Gr. 60/60 } \\
\text { API } \\
\left.\text { Viscosity (cp @ 25 } 25^{\circ} \mathrm{C}\right)\end{array}$ & $\begin{array}{l}0.9330 \\
20.16 \\
540\end{array}$ & $\begin{array}{l}0.9155 \\
23.06 \\
45\end{array}$ \\
\hline Simulated Distillation Data (wt.\%) & & \\
\hline $\begin{array}{l}<305^{\circ} \mathrm{C} \\
305-350^{\circ} \mathrm{C} \\
350-538^{\circ} \mathrm{C} \\
>538^{\circ} \mathrm{C}\end{array}$ & $\begin{array}{l}22.3 \\
11.5 \\
49.6 \\
16.6\end{array}$ & $\begin{array}{r}35.5 \\
15.2 \\
45.8 \\
3.5 \\
\end{array}$ \\
\hline & 100 & 100 \\
\hline
\end{tabular}


Table 2

Boiling Point Distribution of the WRI

As Received and Topped Shale Oil

As Received Shale Oil

(wt.\%)

Topped Shale Oil

(wt.\%)

Gasoline

2.6

0.2

$\left(<200^{\circ} \mathrm{C}\right)$

Kerosene

16.1

11.5

$\left(200-275^{\circ} \mathrm{C}\right)$

Gas Oil

15.8

17.0

$\left(275-325^{\circ} \mathrm{C}\right)$

Hvy GO

27.8

30.9

$\left(325-400^{\circ} \mathrm{C}\right)$

VGO

$\left(400-538^{\circ} \mathrm{C}\right)$

32.5

33.0

Vac. Residue

5.2

7.4

$\left(>538^{\circ} \mathrm{C}\right)$

Total

100

100 
Table 3

Boiling Point Distribution of Fractional

Distillation Cuts from WRI Shale Oil

\begin{tabular}{|c|c|c|c|}
\hline Fraction & $\frac{1}{\left(200-275^{\circ} \mathrm{C}\right)}$ & $\begin{array}{c}2 \\
\left(275-365^{\circ} \mathrm{C}\right)\end{array}$ & $\begin{array}{c}3 \\
\left(365-455^{\circ} \mathrm{C}\right)\end{array}$ \\
\hline Gasoline $\left(<200^{\circ} \mathrm{C}\right)$ & 11.4 wt.\% & -- & -- \\
\hline Kerosene $\left(200-275^{\circ} \mathrm{C}\right)$ & 86.4 & 4.6 & $\cdots$ \\
\hline Gas Oil $\left(275-325^{\circ} \mathrm{C}\right)$ & 2.2 & 41.0 & -- \\
\hline Heavy Gas Oil $\left(325-400^{\circ} \mathrm{C}\right)$ & -- & 54.4 & 12.8 \\
\hline Vacuum Gas Oil $\left(400-538^{\circ} \mathrm{C}\right)$ & -- & -- & 87.2 \\
\hline Total & 100 & 100 & 100 \\
\hline Fractionation Efficiency (\%) & 97.8 & 95.4 & 94.5 \\
\hline
\end{tabular}


Table 4

Physical and Thermodynamic Properties of Distillate Fraction @ 20 and $400^{\circ} \mathrm{C}$

\begin{tabular}{|c|c|c|c|c|c|c|}
\hline Stream ID & $\mathrm{C} 1 \mathrm{~A}$ & $\mathrm{C} 1 \mathrm{~B}$ & $\mathrm{C} 2 \mathrm{~A}$ & $\mathrm{C} 2 \mathrm{~B}$ & $\mathrm{C} 3 \mathrm{~A}$ & $\mathrm{C} 3 \mathrm{~B}$ \\
\hline Stream Phase & Liquid & Liquid & Liquid & Liquid & Liquid & Liquid \\
\hline Mole Frac Liquid & 1.0000 & 1.0000 & 1.0000 & 1.0000 & 1.0000 & 1.0000 \\
\hline Temperature, ${ }^{\circ} \mathrm{C}$ & 20.0000 & 400.0000 & 20.0000 & 400.0000 & 20.0000 & 400.0000 \\
\hline Pressure, psia & 14.7000 & 1500.0000 & 14.7000 & 1500.0000 & 14.7000 & 1500.0000 \\
\hline Enthalpy, mm Btu/ $\mathrm{Hr}$ & -0.0003 & 0.0087 & -0.0002 & 0.0084 & -0.0003 & 0.0080 \\
\hline Entropy, Btu/lb C & 0.3874 & 1.2701 & 0.3054 & 1.1613 & 0.1956 & 1.0120 \\
\hline Act. Dens $\mathrm{lb} / \mathrm{ft}^{3}$ & 56.0335 & 35.3676 & 58.2766 & 40.5101 & 57.4169 & 44.1880 \\
\hline Crit. Temp, ${ }^{\circ} \mathrm{C}$ & 412.3242 & 412.3242 & 490.5108 & 490.5108 & 583.9207 & 583.9207 \\
\hline Crit. Press., psia & 319.4544 & 319.4544 & 255.5638 & 255.5638 & 191.2883 & 191.2883 \\
\hline Crit. Volume, $\mathrm{ft}^{3} / \mathrm{b}$ mole & 10.4114 & 10.4114 & 13.9730 & 13.9730 & 20.0213 & 20.0213 \\
\hline Crit. Compress. $\left({ }^{\circ} \mathrm{C}\right)$ & 0.2491 & 0.2491 & 0.2414 & 0.2414 & 0.2302 & 0.2302 \\
\hline Reduced Temperature & 0.4277 & 0.9820 & 0.3839 & 0.8815 & 0.3420 & 0.7854 \\
\hline Reduced Pressure & 0.0460 & 4.6955 & 0.0575 & 5.8694 & 0.0768 & 7.8416 \\
\hline Acentric Factor & 0.5239 & 0.5239 & 0.6205 & 0.6205 & 0.7596 & 0.7596 \\
\hline Std. Spgr, $\left(\mathrm{H}_{2} \mathrm{O}, 60^{\circ} \mathrm{F}\right)$ & 0.8199 & 0.8199 & 0.8702 & 0.8702 & 0.9323 & 0.9383 \\
\hline Std. API Gravity & 41.0727 & 41.0727 & 31.1093 & 31.1093 & 20.2780 & 20.2780 \\
\hline UOP K (mole basis) & 11.7803 & 11.7803 & 11.6323 & 11.6323 & 11.4497 & 11.4497 \\
\hline Molecular Weight & 178.6985 & 178.6985 & 241.1974 & 241.1974 & 333.4063 & 333.4063 \\
\hline NMIL. Boil Pt. (Mole), C & 225.3356 & 225.3356 & 302.0174 & 302.0174 & 401.1645 & 401.1645 \\
\hline Flash Point, ${ }^{\circ} \mathrm{C}$ & 66.8794 & 66.8794 & 120.5196 & 120.5196 & 178.7225 & 178.7225 \\
\hline $\mathrm{CP}, \mathrm{Btu} / \mathrm{lb} \mathrm{C}$ & 0.8084 & 1.4026 & 0.7628 & 1.3736 & 0.7179 & 1.3802 \\
\hline $\mathrm{CP}$ (CP-4) Ratio & 1.0254 & 1.0145 & 1.0198 & 1.0109 & 1.0152 & 1.0078 \\
\hline Thermal Conductivity Btu/Hr. Ft.F & 0.0679 & 0.0779 & 0.0639 & 0.0549 & 0.0605 & 0.0401 \\
\hline Viscosity, $\mathrm{cp}$ & 2.0372 & 0.1138 & 7.3194 & 0.1596 & 133.6496 & 0.2733 \\
\hline Surf. Tens., Dynes'cm & 29.1007 & 0.8666 & 32.2362 & 4.4358 & 35.4442 & 9.1950 \\
\hline
\end{tabular}

$$
1=200-275 ; 2=275-365 ; 3=365-455
$$


Table 5

Catalyst Properties

Catalyst

Nominal size, in (mm)

Chemical composition, wt.\%

Cobalt

Molybdenum
344 T/L 1/16

$1 / 16(1.5)$

2.52

9.85

Physical properties

Surface area, $\mathrm{m}^{2} / \mathrm{g}$

Pore volume, $\mathrm{cc} / \mathrm{g}$

Side plate crush strength, lb

Attrition index

Compacted bulk density, $\mathrm{lbs} / \mathrm{ft}^{3}$

Loss on ignition at $900^{\circ} \mathrm{F}$, wt.\%
190

0.56

22.5

98.8

45.0

1.24
9.59

444 T/L $1 / 16$

$1 / 16(1.5)$

\subsection{2}

$$
9.59
$$

230

0.57

19.4

98.8

45.4

0.99 
Table 6

Projected Results

\begin{tabular}{|c|c|c|c|}
\hline (percent) & Feed & $\begin{array}{c}\text { Conventional } \\
\text { Upgrading }\end{array}$ & $\begin{array}{c}\text { Proposed } \\
\text { Upgrading }\end{array}$ \\
\hline \multicolumn{4}{|l|}{ Liquids } \\
\hline $\begin{array}{l}60-200^{\circ} \mathrm{C} \\
200-350^{\circ} \mathrm{C} \\
200-350^{\circ} \mathrm{C} \\
350-425^{\circ} \mathrm{C} \\
\text { Coke }\end{array}$ & $\begin{array}{r}12 \\
38 \\
24 \\
26 \\
--\end{array}$ & $\begin{array}{c}14 \\
41 \\
24 \\
24 \\
0.2\end{array}$ & $\begin{array}{c}34 \\
57 \\
7 \\
2 \\
1.3\end{array}$ \\
\hline Coke & 100 & 103.2 & 101.3 \\
\hline \multicolumn{4}{|c|}{ H Consumption } \\
\hline $\begin{array}{l}\text { wt } \% \\
\text { scf/bbl (feed) }\end{array}$ & $\begin{array}{l}-- \\
--\end{array}$ & $\begin{array}{c}3.2 \\
2000\end{array}$ & $\begin{array}{l}1.3 \\
800\end{array}$ \\
\hline
\end{tabular}




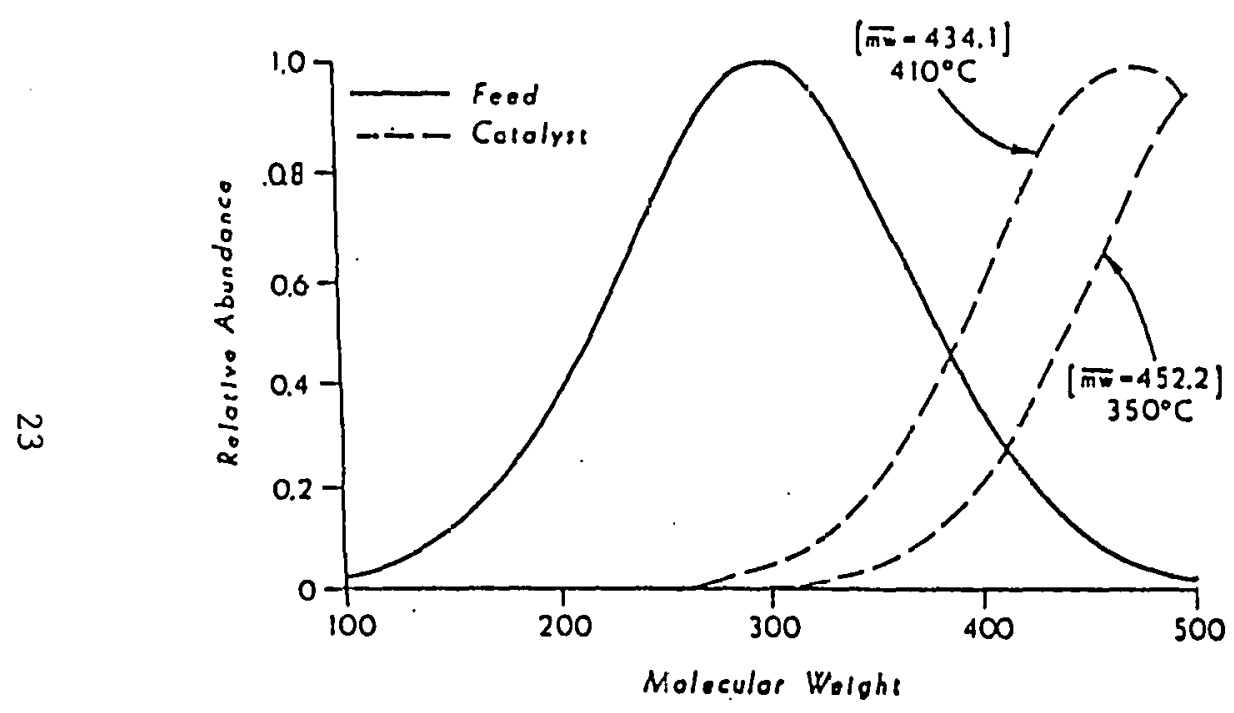

(a) Broad M.W. Range

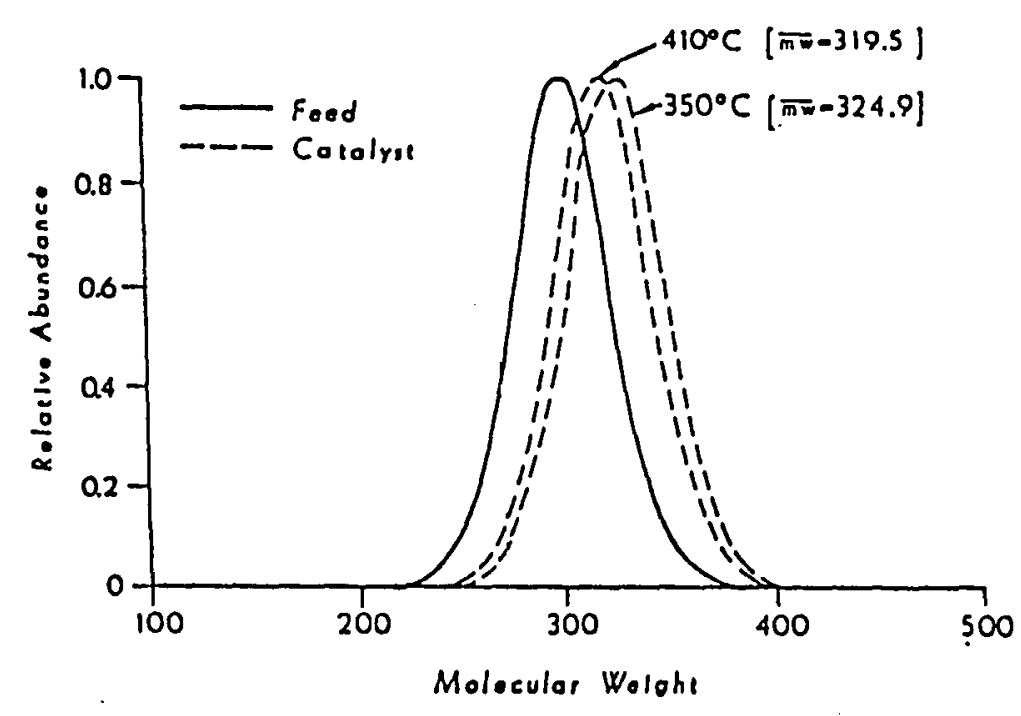

(b) Narrow M.W. Range

Figure 1

Composition of Feed Streams and Adsorbed Species 


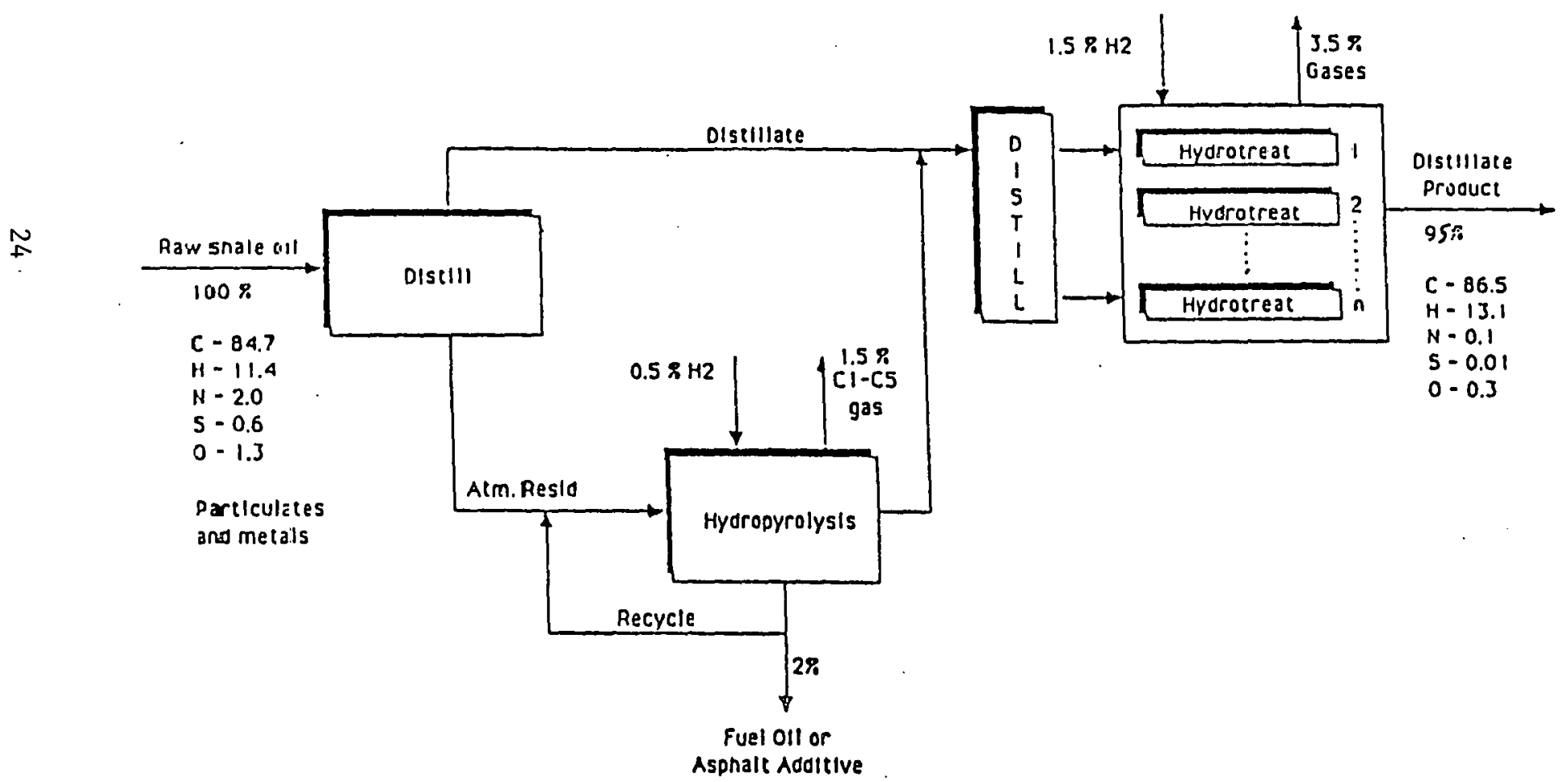

Figure 2

Shale Oil Upgrading Process

Flow Diagram and Material Balance Projected 
a) Gas

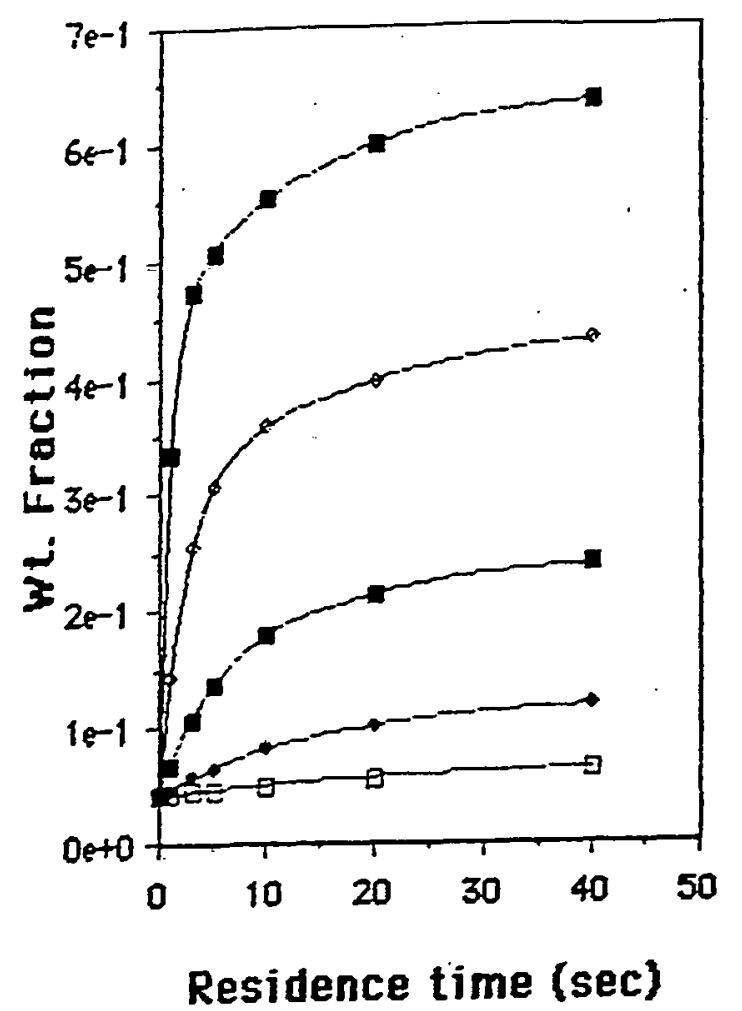

:) Atmospheric and Vacuum Distillate

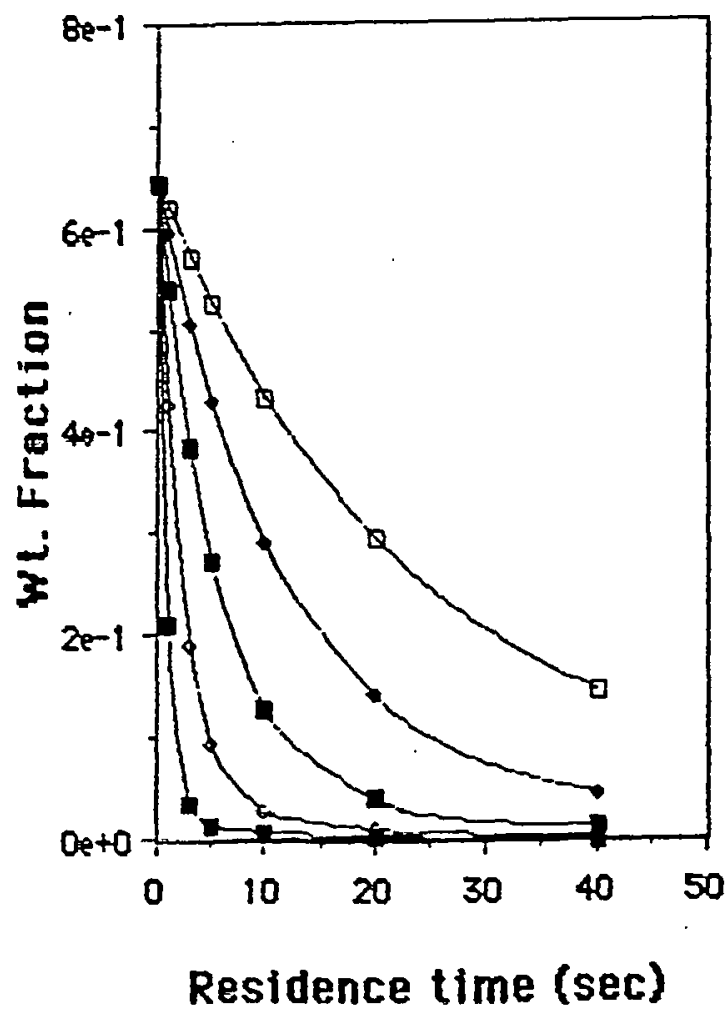

b) Naphtha+Middle Distillate

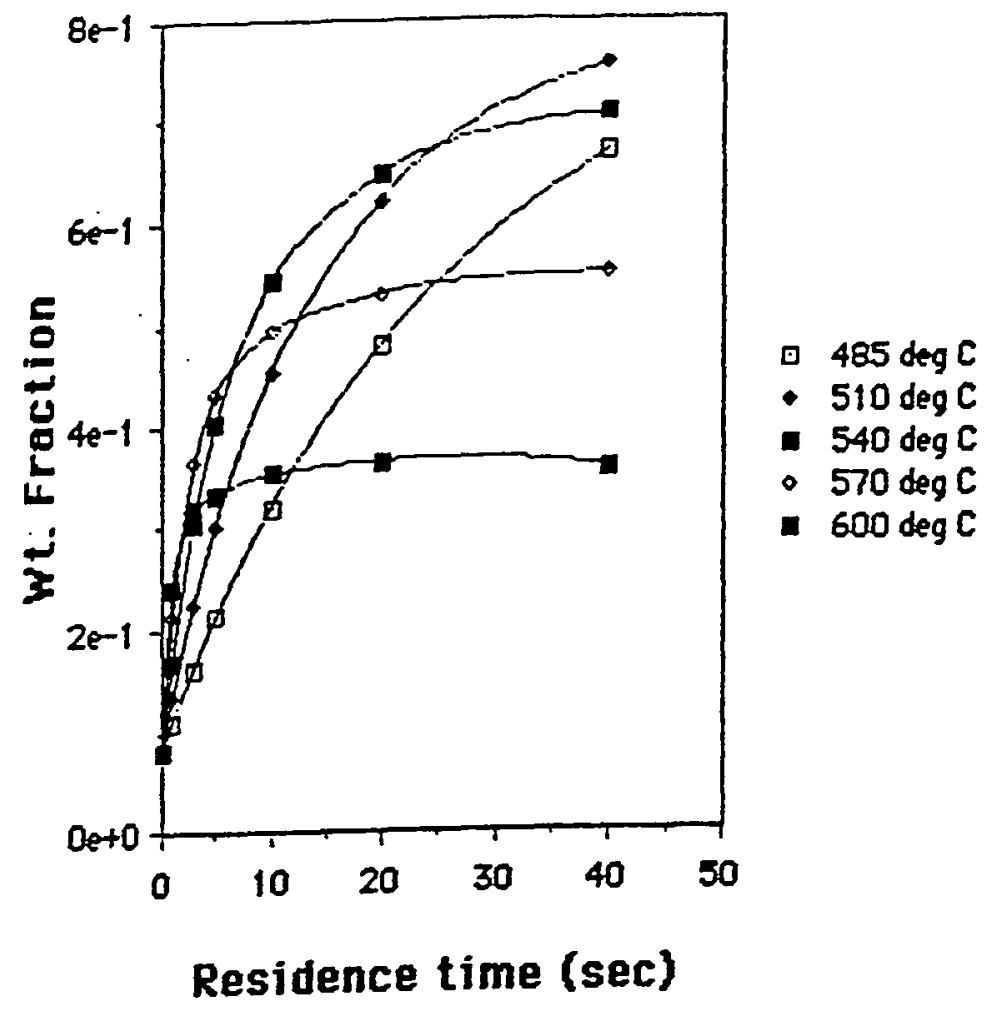

d) Residue

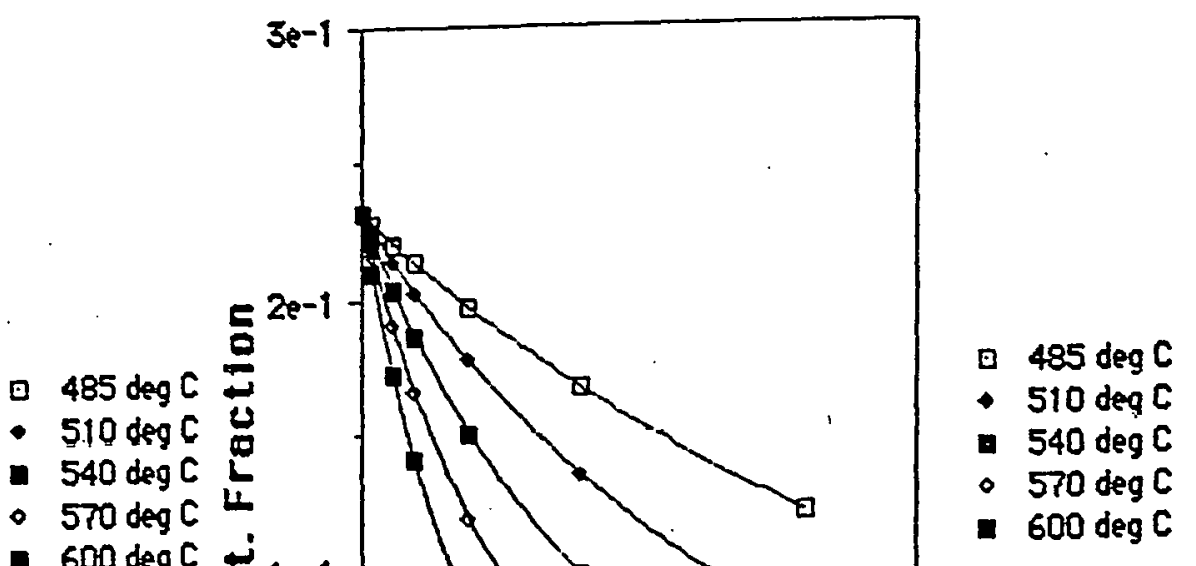

Figure 3 